\title{
FUNGSI KONJUNGTOR “YANG” PADA KALIMAT BERSUSUN DALAM TEKS BERITA DI MEDIA DARING
}

\author{
Sulis Setiawati \\ Program Studi Pendidikan Bahasa Indonesia, \\ Fakultas Bahasa dan Seni, Universitas Indraprasta PGRI \\ sulisjbsi@gmail.com
}

\begin{abstract}
Abstrak
Konjungtor adalah kata sambung yang digunakan untuk menggabungkan antarsatuan bahasa dalam sebuah kalimat, antarkalimat, atau antarparagraf. Konjungtor "yang” merupakan salah satu konjungtor subordinatif kelompok atributif. Pada kalimat bersusun, konjungtor "yang" berfungsi sebagai penanda keterangan salah satu fungsi kalimat. Penelitian ini bertujuan mengidentifikasi penggunaan konjungtor "yang" pada kalimat bersusun pada teks berita di media daring. Metode yang digunakan adalah kualitatif deskriptif dengan teknik analisis isi. Data berupa teks berita bersumber dari kompas.com edisi 20 April 2019. Dari media tersebut, dipilih 10 artikel secara acak. Berdasarkan hasil analisis 10 teks berita, ditemukan 11 data penggunaan konjungtor "yang” sebagai keterangan fungsi Subjek, 17 data sebagai keterangan Objek, 5 data sebagai keterangan fungsi Keterangan, dan 1 data sebagai keterangan Pelengkap. Tidak ditemukan data penggunaan konjungtor "yang" sebagai keterangan fungsi Predikat. Fakta lain yang ditemukan dalam penelitian ini adalah mengenai ketidaktepatan penggunaan konjungtor dalam beberapa artikel yang dianalisis. Dengan analisis penggunaan konjungtor dalam media massa, kita dapat mengetahui dan mengklasifikasi fungsi konjungtor tersebut dalam konteks teks berita.
\end{abstract}

Kata Kunci: Konjungtor, kalimat bersusun, teks berita

\begin{abstract}
Conjunction or conjunctions are particles used to combine words with words, phrases with phrases, clauses with clauses, sentences with sentences, or paragraphs with paragraphs. The conjunction "yang" is one of the attribute subordinative conjunctions. In compounded sentences, the conjunction "yang" functions as a marker of information on one of the functions of a sentence. This study aims to identify the use of the conjunction "yang" in multilevel sentences in news texts in online mass media. The method used is descriptive qualitative with content analysis techniques. The data source in the form of news text analyzed in this study is kompas.com on the 20 April 2019 edition. From the media, 10 news texts were randomly selected. Based on the results of the analysis of 10 articles, it was found 11 data on the use of the conjunction "yang" as a description of the subject's function, 17 data as an object description, 5 data as a description of the function description, and 1 data as supplementary information. There is no data on the use of the conjunction "yang" as a description of the Predicate function. Another fact found in this study is the inaccuracy of using the conjunction in several articles analyzed. By analyzing the use of conjunction in mass media, we can find out and classify the functions of the conjunction in the context of news texts.
\end{abstract}

Keywords: Conjunction, compounded sentences, news texts

\section{PENDAHULUAN}

Ilmu bahasa atau linguistik dapat ditelaah dengan kajian mikrolinguistik atau makrolinguistik. Kajian mikrolinguistik terdiri atas fonologi, morfologi, sintaksis, semantik, dan 
leksikologi. Ruang lingkup kajian mikrolinguistik hanya terbatas pada struktur bahasa, sedangkan makrolinguistik ruang lingkup kajiannya lebih luas karena merupakan penggabungan antara linguistik dengan disiplin ilmu lain. Contoh kajian makrolinguistik adalah sosiolinguistik, psikolinguistik, dan lain-lain.

Sintaksis adalah salah satu telaah bahasa mikrolinguistik. Dalam Chaer (Chaer, 2012) dijelaskan bahwa kata sintaksis berasal dari bahasa Yunani yaitu sun yang berarti dengan dan kata tattein yang berarti menempatkan. Jadi, kata sintaksis dapat diartikan menempatkan bersama-sama kata-kata menjadi kelompok kata (Chaer, 2012). Pengertian ini seakan menjelaskan bahwa sintaksis merupakan bagian dari sebuah subsistem bahasa.

Sebagai suatu subsistem bahasa, sintaksis membahas hubungan kata dengan satuan yang lebih besar yang membentuk sebuah kalimat (H.P., 2012). Fungsi kalimat atau fungsi sintaksis merupakan pembahasan yang terdapat dalam kajian sintaksis. Fungsi kalimat yang dimaksud terdiri dari subjek (S), predikat $(\mathrm{P})$, objek $(\mathrm{O})$, keterangan (Ket.), dan pelengkap (Pel.)

Dalam Alwi (Alwi, 2014) disebutkan bahwa subjek pada umumnya berupa nomina, frasa nominal, frasa verbal, atau klausa. Subjek biasanya terdapat di sebelah kiri predikat atau bisa juga berada di akhir kalimat jika subjeknya lebih panjang dibandingkan dengan predikat, sedangkan predikat adalah fungsi pokok yang disertai subjek di sebelah kiri dan jika ada, objek, pelengkap, dan keterangan di sebelah kanan. Predikat dapat berupa frasa verbal, ajektival, nominal, numeral, atau preposisional. Fungsi yang ketiga adalah objek yaitu unsur kalimat yang kehadirannya tergantung pada kata kerja yang mengisi fungsi predikat. Letak objek selalu langsung setelah predikatnya. Pelengkap berada langsung di belakang predikat jika tidak ada objek dan di belakang objek jika unsur ini ada. Ciri khas pelengkap yaitu tidak dapat menjadi subjek apabila kalimat tersebut diubah menjadi pasif. Berikutnya adalah keterangan. Keterangan adalah fungsi sintaksis yang letaknya paling fleksibel atau mudah berpindah letak. Biasanya berupa frasa nominal, preposisional, atau adverbial (Alwi, 2014). Dari kelima fungsi kalimat tersebut, fungsi yang wajib ada dalam sebuah kalimat adalah subjek dan predikat. Fungsi objek hadir hanya apabila predikat menghendakinya. Begitu juga dengan pelengkap dan keterangan, bukanlah merupakan fungsi yang wajib.

Terkait dengan jenis kalimat, berdasarkan jenis klausa dalam kalimat, kalimat dikelompokkan menjadi kalimat tunggal, kalimat bersusun, dan kalimat majemuk (H.P., 2012). Kalimat merupakan satuan bahasa terkecil yang mengungkapkan pikiran atau informasi secara utuh (Sasangka, 2016). Jika ada sebuah ujaran yang memberikan informasi, tetapi belum lengkap atau belum utuh, ujaran itu belum dapat disebut kalimat. Ciri lain tuturan disebut kalimat adalah adanya fungsi predikat dalam tuturan tersebut.

Kalimat bersusun adalah kalimat yang mempunyai pola: (H.P., 2012)

a) $\mathrm{S}+$ Ket. $\mathrm{S}+\mathrm{P}+\mathrm{O} \pm$ Ket. $\left(\begin{array}{l}\mathrm{FN} \\ <\text { dengan }> \\ \text { yang }\end{array}\right)$

Pola kalimat tersebut dapat dibaca: Subjek diikuti keterangan, diikuti Predikat, diikuti Objek, dengan atau tanpa diikuti oleh Keterangan.

Contoh: 
Masalah[S] yang ramai dibicarakan[Ket.S] mendapat[P] perhatian pemerintah[O].

b) $\mathrm{S} 1+\mathrm{P} 1 \pm \mathrm{O}+$ Konj. $\quad \pm$ $\mathrm{S} \mathrm{P} \pm \mathrm{O} 2+\mathrm{P} \pm \mathrm{O} \pm$ Pel. \pm Ket.

$$
\left(\begin{array}{c}
\text { karena } \\
<\text { sebab }> \\
\text { sejak }
\end{array}\right)
$$

Contoh:

Saya[S1] tidak dapat datang[P1] hari ini[Ket.] karena saya[S] harus mengantarkan[P] anak saya[O] ke sekolah[K].

c) Konj. $+\mathrm{S}+\mathrm{P} 1 \pm$ Pel. \pm Ket., $\mathrm{S} 2+\mathrm{P} 2 \pm \mathrm{O} 2 \pm \mathrm{Pel} \pm$ Ket. 2

$\left(\begin{array}{l}\text { karena } \\ \text { sebab } \\ \text { sejak }\end{array}\right)$

Contoh:

Sebab ia[S] sakit[P], ia[S] tidak bisa datang[P].

d) $\mathrm{S} 1+\mathrm{P} 1 \pm$ bahwa $+\mathrm{O} 1+\mathrm{O} 2+\mathrm{P} 2$ $+\mathrm{O} 2$

Contoh:

$\mathrm{Ibu}[\mathrm{S}]$ mengatakan[P] bahwa $\mathrm{ia}[\mathrm{O} 1]$ akan pergi sebentar[P].

Pada pola kalimat bersusun yang pertama (pola a), didapati penggunaan konjungtor "yang" yang berfungsi sebagai keterangan subjek (Ket. S). Dalam Kridalaksana (Kridalaksana, 2008), konjungtor atau konjungsi adalah partikel untuk menggabungkan antarkata, antarfrase, antarklausa, antarkalimat, atau antarparagraf (Kridalaksana, 2008). Konjungtor "yang" merupakan konjungtor subordinatif yang mempunyai hubungan atributif (Alwi, 2014). Hubungan subordinatif berarti konjungtor "yang" berfungsi menghubungkan antarsatuan bahasa dalam satu kalimat. Satuan tersebut bisa antarkata, antarfrase, atau antarklausa.

Penelitian tentang konjungtor atau konjungsi sebelumnya membahas tentang konjungsi sebagai salah satu aspek kohesi (Setiawati, 2015), sedangkan penelitian ini lebih fokus pada penggunaan konjungsi "yang" yang berfungsi sebagai penanda keterangan pada salah satu fungsi kalimat dalam teks berita di media daring.

Media daring yang dimaksud mengacu pada media massa yang dipublikasi secara online atau daring. Media massa adalah sebuah saluran komunikasi dan informasi yang digunakan untuk menyebarkan informasi secara massal dan dapat diakses oleh masyarakat secara massal pula (Komunikasi, Drs, Mulyana, \& Si, 2016). Mulyana (Komunikasi et al., 2016) menjelaskan, ada tiga jenis media massa, yaitu (1) media cetak atau printed media misalnya surat kabar atau koran, majalah, tabloid, (2) media elektronik atau electronic media misalnya radio, televisi, film, dan (3) media daring atau media online berupa situs web atau website.

Dalam penelitian ini, media yang dijadikan sumber data penelitian adalah situs berita Kompas.com. edisi 20 April 2019.

\section{METODE PENELITIAN}

Penelitian ini menggunakan metode kualitatif deskriptif. Teknik yang digunakan adalah analisis isi (content analysis). Penelitian ini dilakukan pada 10 teks berita yang terdapat pada media daring Kompas.com., edisi Sabtu 20 April 2019. Sepuluh teks berita yang dianalisis, diambil dari rubrik yang berbeda secara acak. Rubrik yang terpilih tersebut yaitu Rubrik Edukasi, Internasional, Regional, dan Nasional. Langkah berikutnya adalah mengidentifikasi kalimat dalam teks 
berita tersebut yang menggunakan konjungtor "yang", melakukan analisis, dan penarikan simpulan.

\section{HASIL DAN PEMBAHASAN}

\section{a. Hasil}

Dari 10 teks berita yang dianalisis, ditemukan 11 data penggunaan konjungtor "yang" sebagai keterangan fungsi Subjek, 17 data sebagai keterangan Objek, 5 data sebagai keterangan fungsi Keterangan, dan 1 data sebagai keterangan Pelengkap. Tidak ditemukan data penggunaan konjungtor "yang" sebagai

keterangan fungsi Predikat. Fakta lain yang ditemukan dalam penelitian ini adalah mengenai ketidaktepatan penggunaan konjungtor dalam beberapa artikel yang dianalisis. Namun, hal tersebut tidak menjadi fokus dalam penelitian ini.

\section{b. Pembahasan}

Berikut adalah daftar judul artikel yang dipilih secara acara sebagai sumber data penelitian.

Tabel 1 Daftar Judul Teks Berita yang Dianalisis

\begin{tabular}{|c|c|c|c|}
\hline No. & Judul Teks Berita & Rubrik & url \\
\hline 1 & $\begin{array}{l}\text { "Politeknik Harus Dibangun } \\
\text { untuk Kembangkan Potensi } \\
\text { Daerah" (Harususilo, 2019c) }\end{array}$ & Edukasi & $\begin{array}{l}\text { https://edukasi.kompas.com/read/2019/04/20/2339 } \\
\text { 0251/politeknik-harus-dibangun-untuk- } \\
\text { kembangkan-potensi-daerah }\end{array}$ \\
\hline 2 & $\begin{array}{l}\text { "Kasus Siswi Dibakar di } \\
\text { Bangladesh, Perdana Menteri } \\
\text { Buka Suara"(Perdana, 2019) }\end{array}$ & Internasional & $\begin{array}{l}\text { https://internasional.kompas.com/read/2019/04/20/ } \\
\text { 23344161/kasus-siswi-dibakar-di-bangladesh- } \\
\text { perdana-menteri-buka-suara }\end{array}$ \\
\hline 3 & $\begin{array}{l}\text { "UGM Bermitra dengan Industri } \\
\text { Manfaatkan r Hasil } \\
\text { Penelitian"(Harususilo, 2019e) }\end{array}$ & Edukasi & $\begin{array}{l}\text { https://edukasi.kompas.com/read/2019/04/20/2327 } \\
\text { 1121/ugm-bermitra-dengan-industri-manfaatkan- } \\
\text { hasil-penelitian }\end{array}$ \\
\hline 4 & $\begin{array}{l}\text { "Dukung Jokowi, Bima Arya } \\
\text { Mengaku Hubungan dengan } \\
\text { PAN Tetap Baik"(Gatra, 2019a) }\end{array}$ & Regional & $\begin{array}{l}\underline{\text { https://regional.kompas.com/read/2019/04/20/2325 }} \\
\text { 3061/dukung-jokowi-bima-arya-mengaku- } \\
\text { hubungan-dengan-pan-tetap-baik }\end{array}$ \\
\hline 5 & $\begin{array}{l}\text { "Upaya LIPI Mewujudkan } \\
\text { Pemulihan } \\
\text { Citarum"(Harususilo, 2019f) }\end{array}$ & Edukasi & $\begin{array}{l}\text { https://edukasi.kompas.com/read/2019/04/20/2317 } \\
\underline{\text { 1301/upaya-lipi-mewujudkan-pemulihan-citarum. }} .\end{array}$ \\
\hline 6 & $\begin{array}{lr}\text { "Politeknik Negeri } & \text { Pontianak } \\
\text { Gelar } & \text { BEM } \\
\text { Awards"(Harususilo, 2019d) }\end{array}$ & Edukasi & $\begin{array}{l}\underline{\text { https://edukasi.kompas.com/read/2019/04/20/2303 }} \\
\underline{\text { 4801/politeknik-negeri-pontianak-gelar-bem- }} \\
\underline{\text { awards }}\end{array}$ \\
\hline 7 & $\begin{array}{lcr}\text { "Gandeng } & \text { AMCF, } & \text { Pemkot } \\
\text { Makassar } & \text { Operasi } & \text { Gratis } \\
\text { Ratusan } & & \text { Pasien } \\
\text { Katarak"(Gewati, 2019) } & \end{array}$ & Regional & $\begin{array}{l}\overline{\text { https://regional.kompas.com/read/2019/04/20/2253 }} \\
\text { 3601/gandeng-amcf-pemkot-makassar-operasi- } \\
\text { gratis-ratusan-pasien-katarak }\end{array}$ \\
\hline 8 & $\begin{array}{l}\text { "Polri: } 9 \text { Polisi Gugur Selama } \\
\text { Pemilu"(Gatra, 2019b) }\end{array}$ & Nasional & $\begin{array}{l}\text { https://nasional.kompas.com/read/2019/04/20/2253 } \\
\text { 0141/polri-9-polisi-gugur-selama-pemilu. }\end{array}$ \\
\hline 9 & $\begin{array}{lcr}\text { "Belajar } & \text { Kasus } & \text { Pontianak, } \\
\text { Begini } & \text { Cara } & \text { Orangtua } \\
\text { Mendekati Remaja"(Harususilo, } \\
\text { 2019b) }\end{array}$ & Edukasi & $\begin{array}{l}\text { https://edukasi.kompas.com/read/2019/04/20/2249 } \\
\text { 0541/belajar-kasus-pontianak-begini-cara- } \\
\text { orangtua-mendekati-remaja. }\end{array}$ \\
\hline 10 & $\begin{array}{l}\text { "4 Alasan Banyak Les } \text { Justru } \\
\text { Sebabkan Anak } \quad \text { Tidak } \\
\text { Berhasil!"(Harususilo, 2019a) }\end{array}$ & Edukasi & $\begin{array}{l}\text { https://edukasi.kompas.com/read/2019/04/20/2219 } \\
\text { 0251/4-alasan-banyak-les-justru-sebabkan-anak- } \\
\text { tidak-berhasil. }\end{array}$ \\
\hline
\end{tabular}

Temuan data berupa penggunaan konjungtor "yang" yang berfungsi sebagai penanda salah satu fungsi kalimat dalam teks berita yang dianalisis dapat diklasifikasikan sebagai berikut: a) Sebagai Keterangan Subjek (Ket. Subjek)

1. Kasus pembunuhan seorang remaja putri[S] yang dibakar karena menuduh seorang guru melakukan pelecehan 
seksual[Ket.S] telah memicu[P] terjadinya aksi demontrasi warga [O]. (Teks 2)(Perdana, 2019)

2. Gadis bernama Nusrat Jahan Rafi[S], yang baru berusia 19 tahun [Ket.S], tewas [P] setelah dibakar hidup-hidup [K]. (Teks 2)(Perdana, 2019)

3. Sebuah video[S] yang beredar[Ket.S] menunjukkan[P] bahwa kepala kantor polisi setempat sempat mendaftarkan pengaduannya[O]. (Teks 2)(Perdana, 2019)

4. Pemimpin lokal partai Liga Awami[S] yang berkuasa [Ket.S] telah ditahan[P]. (Teks 2)(Perdana, 2019)

5. Politisi [O] yang juga Wali Kota Bogor Bima Arya Sugiarto [Ket.S] menegaskan[P] hubungan antara dirinya dengan jajaran pengurus parpol tempatnya bernaung, yakni Partai Amanat Nasional (PAN) baik-baik saja[O] (Teks 4)(Gatra, 2019a)

6. Jajaran elite dan pengurus PAN[S] yang hadir pada pelantikan Bima Arya tersebut [Ket.S] ialah dari DPW PAN Jawa Barat dan anggota Fraksi Golkar Amanah DPRD Jawa Barat seperti Herry Dermawan [P] (Teks 4)(Gatra, 2019a)

7. Operasi katarak[S] yang digelar di Balai Kesehatan Mata Masyarakat (BKMM), Jl Wijaya Kusuma No 19, Kompleks Kesehatan, Kelurahan Banta Bantaeng, Makassar, Sabtu (21/4/2019) itu [Ket.S] adalah program kapal kemanusiaan 04 [P].(Teks 7)(Gewati, 2019)

8. Program $[\mathrm{S}]$ yang didirikan tahun 2015 tersebut [Ket.S] bertujuan $[\mathrm{P}]$ untuk melaksanakan berbagai kegiatan kemanusiaan di
Indonesia [Pel] (Teks 7)(Gewati, 2019)

9. Pada hari pertama operasi katarak mata $[\mathrm{K}]$, tim dokter[S] yang disiapkan [Ket.S] telah mengoperasi[P] sebanyak 71 pasien[O] (Teks 7)(Gewati, 2019)

10. Seluruh anggota Polri[S] yang gugur dalam tugas pengamanan Pemilu $2019 \quad$ [Ket.S], mendapatkan[P]

penghargaan[O] dari Kapolri Jenderal Pol Tito Karnavian berupa kenaikan pangkat satu tingkat lebih tinggi[K] (Teks 8)(Gatra, 2019b)

11. Sedikitnya ada sembilan anggota Polri[S] yang meninggal dunia[Ket.S] saat melaksanakan $[\mathrm{P}] \quad$ tugas pengamanan Pemilu 2019[O] (Teks 8)(Gatra, 2019b)

b) Sebagai Keterangan Objek (Ket. O)

1. Kabupaten Bima[S] memiliki[P] potensi kekayaan alam[O] yang besar [Ket.O]. (Teks 1)(Harususilo, 2019c)

2. Pada kesempatan ini[K] Menristekdikti[S] kembali mengingatkan $[\mathrm{P}]$ saat ini Negara[O] yang maju bukan ditentukan oleh jumlah sumber daya alam ataupun jumlah penduduk, namun penguasaan teknologi dan inovasi [Ket.O]. (Teks 1)(Harususilo, 2019c)

3. Mohamad Nasir[S] mengapresiasi $[\mathrm{P}] \quad$ jajaran pemerintah Kabupaten Bima[O] yang memiliki semangat memiliki Lembaga Pendidikan Tinggi [Ket.O]. (Teks 1)(Harususilo, 2019c)

4. Bupati Kabupaten Bima, Indah Dhamayanti Putri[S] 
menyampaikan[P] kepada

Menristekdikti Vokasi

Unram[O] yang berada di

Kabupaten Bima[ket.O] (Teks

1)(Harususilo, 2019c)

5. Korban[S] kemudian dibawa[P] ke atap sekolah seminari tempatnya belajar[K] dan didesak mencabut $[\mathrm{P}]$ laporan tuduhan pemerkosaan[O] yang ditujukan kepada kepala sekolah[Ket.O]. (Teks 2)(Perdana, 2019)

6. Kerja sama tersebut[S] dituangkan[P] dalam penandatanganan nota kesepahaman bersama[O] yang dilakukan oleh Rektor UGM, Prof. Panut Mulyono dan Direktur Utama PT RNI Didik Prasetyo Selasa (16/4/2019) [Ket.O] di ruang tamu pimpinan, Gedung Pusat UGM. [K] (Teks 3)(Harususilo, 2019e)

7. Rektor[S] mengatakan[P] UGM sebagai salah satu perguruan tinggi[O] bertugas mengembangkan $[\mathrm{P}]$ ilmu pengetahuan dan produk penelitian[O] yang diharapkan bisa dihilirkan ke masyarakat [Ket.O] (Teks 3)(Harususilo, 2019e)

8. Ia[S] menyebutkan[P] salah satu produk kesehatan[O] yang kini tengah dalam proses pengembangan[Ket.O] (Teks 3)(Harususilo, 2019e)

9. LPTB LIPI[S] telah mengembangkan $[\mathrm{P}]$ teknologi toilet pengompos[O] yang sesuai untuk diterapkan di lingkungan yang sulit air bersih dan kekurangan sarana sanitasi [Ket.O] (Teks 5)(Harususilo, 2019f)

10. LIPI[S] telah mengembangkan $[\mathrm{P}]$ metode yang lebih mudah dan cepat untuk memonitor zat-zat[O] yang terkandung pada zat pewarna tekstil[Ket.O] (Teks 5)(Harususilo, 2019f)

11. Kegiatan[S] dibuka[P] Direktur[O] yang didampingi Pembantu Direktur Politeknik Negeri Pontianak [Ket.O] (Teks 6)(Harususilo, 2019d)

12. Penutup kegiatan[S] dilakukan $[\mathrm{P}]$ jalan sehat $[\mathrm{O}]$ yang diikuti seluruh mahasiswa dilingkungan Politeknik Negeri Pontianak [Ket.O] (Teks 6)(Harususilo, 2019d)

13. AMCF sendiri[S] menyelenggarakan $[\mathrm{P}] \quad$ bakti sosial[O] membantu[P] masyarakat[O] yang menderita katarak mata, khususnya kaum fakir yang tidak mempunyai biaya atau BPJS[Ket.O] (Teks 7)(Gewati, 2019)

14. Haeruddin[S] mengatakan[P] bahwa bakti sosial[O] yang diadakan di Makassa adalah yang pertama kali [Ket.O] (Teks 7)(Gewati, 2019)

15. Pihaknya pun[S] menyatakan[P] duka[O] yang mendalam atas gugurnya putra-putra terbaik korps berbaju cokelat tersebut [Ket.O] (Teks 8)(Gatra, 2019b)

16. Orangtua[S] tetap memiliki[P] ikatan dan komunikasi[O] yang tidak kalah kuat[Ket.O] dengan ikatan anak remaja dengan kawan sebayanya[K] (Teks 9)(Harususilo, 2019b)

17. Penelitian[S] menemukan[P] anak-anak usia $\mathrm{SD}[\mathrm{O}]$ yang mengikuti ekskul dan kegiatan tambahan di luar sekolah hingga 4-5 kali dalam seminggu bahkan hingga sampai larut malam, membuatnya mudah kelelahan dan tidak fokus sehingga jarang 
menghabiskan waktu berkualitas bersama keluarga [Ket.O] (Teks 10)(Harususilo, 2019a)

c) Sebagai Keterangan Fungsi Keterangan (Ket. K)

1. Politeknik[S] harus dibangun[P] di tempat [O] yang memiliki potensi sumber daya alam [Ket.K]. (Teks 1)(Harususilo, 2019c)

2. Hal ini[S] sejalan[P] dengan kebijakan Kemenristekdikti[K] yang salah satu fokusnya adalah pendidikan vokasi dan politeknik yang akan menjadi motor penghasil sumber daya manusia (SDM) terampil [Ket.K]. (Teks 1)(Harususilo, 2019c)

3. Perdana Menteri Bangladesh Sheikh Hasina[S], juga telah buka suara[P] atas kasus ini[O] dengan berjanji[K] semua yang terlibat akan mendapat hukuman [Ket.K] (Teks 2)(Perdana, 2019)

4. Namun nyawanya[S] tidak terselamatkan[P] akibat luka bakar parah[K] yang mencapai 80 persen [Ket.K] (Teks 2)(Perdana, 2019)

5. Sikap Bima Arya tersebut[S] bertolak belakang[P] dengan keputusan DPP PAN[K] yang mendukung pasangan Prabowo Subianto-Sandiaga Uno[Ket.K] (Teks 4)(Gatra, 2019a)

\section{d) Sebagai Keterangan Pelengkap (Ket.Pel)}

1. Menteri Nasir[S] berharap[P] politeknik[Pel] yang akan didirikan di Kabupaten Bima dapat mengangkat potensi daerah tersebut [Ket.Pel]. (Teks 1)(Harususilo, 2019c)

\section{SIMPULAN}

Konjungtor adalah kata sambung yang digunakan untuk menggabungkan antarsatuan bahasa dalam sebuah kalimat, antarkalimat, atau antarparagraf. Pada kalimat bersusun, konjungtor "yang" berfungsi sebagai penanda keterangan salah satu fungsi kalimat.

Berdasarkan hasil analisis 10 teks berita, ditemukan 11 data penggunaan konjungtor "yang" sebagai keterangan fungsi Subjek, 17 data sebagai keterangan Objek, 5 data sebagai keterangan fungsi Keterangan, dan 1 data sebagai keterangan Pelengkap. Tidak ditemukan data penggunaan konjungtor "yang" sebagai keterangan fungsi Predikat.

Melalui penelitian ini dapat dibuktikan bahwa penggunaan konjungtor "yang" tidak hanya berfungsi sebagai penanda keterangan fungsi Subjek, tetapi juga dapat digunakan sebagai keterangan fungsi kalimat pada objek, keterangan, dan pelengkap.

\section{DAFTAR PUSTAKA}

Alwi, H. dkk. (2014). Tata Bahasa Baku Bahasa Indonesia (Edisi Keti). Jakarta: Balai Pustaka.

Chaer, A. (2012). Linguistik Umum. Jakarta: Rineka Cipta.

Gatra, S. (2019a). Dukung Jokowi, Bima Arya Mengaku Hubungan dengan PAN Tetap Baik. Retrieved April 27, 2019, from https://regional.kompas.com/rea d/2019/04/20/23253061/dukung -jokowi-bima-arya-mengakuhubungan-dengan-pan-tetapbaik

Gatra, S. (2019b). Polri: 9 Polisi Gugur Selama Pemilu. Retrieved from https://nasional.kompas.com/rea 
d/2019/04/20/22530141/polri-9polisi-gugur-selama-pemilu

Gewati, M. (2019). Gandeng AMCF, Pemkot Makassar Operasi Gratis Ratusan Pasien Katarak. Retrieved April 27, 2019, from https://regional.kompas.com/rea d/2019/04/20/22533601/ganden g-amcf-pemkot-makassaroperasi-gratis-ratusan-pasienkatarak

H.P., A. (2012). Sintaksis Bahasa Indonesia (Cetakan ke). Jakarta: Pustaka Mandiri.

Harususilo, Y. E. (2019a). 4 Alasan Banyak Les Justru Sebabkan Anak Tidak Berhasil. Retrieved April 27, 2019, from https://edukasi.kompas.com/read /2019/04/20/22190251/4-alasanbanyak-les-justru-sebabkananak-tidak-berhasil

Harususilo, Y. E. (2019b). Belajar Kasus Pontianak, Begini Cara Orangtua Mendekati Remaja. Retrieved April 27, 2019, from https://edukasi.kompas.com/read /2019/04/20/22490541/belajarkasus-pontianak-begini-caraorangtua-mendekati-remaja

Harususilo, Y. E. (2019c). Politeknik Harus Dibangun untuk Kembangkan Potensi Daerah. Retrieved April 27, 2019, from https://edukasi.kompas.com/read /2019/04/20/23390251/politekni k-harus-dibangun-untukkembangkan-potensi-daerah.

Harususilo, Y. E. (2019d). Politeknik Negeri Pontianak Gelar BEM Awards. Retrieved April 27, 2019,

from https://edukasi.kompas.com/read /2019/04/20/23034801/politekni k-negeri-pontianak-gelar-bemawards

Harususilo, Y. E. (2019e). UGM Bermitra dengan Industri Manfaatkan Hasil Penelitian. Retrieved April 27, 2019, from https://edukasi.kompas.com/read /2019/04/20/23271121/ugmbermitra-dengan-industrimanfaatkan-hasil-penelitian

Harususilo, Y. E. (2019f). Upaya LIPI Mewujudkan Pemulihan Citarum. Retrieved April 27, 2019, from https://edukasi.kompas.com/read /2019/04/20/23171301/upayalipi-mewujudkan-pemulihancitarum

Komunikasi, S., Drs, D., Mulyana, A., \& $\mathrm{Si}$, M. (2016). KOMUNIKASI MASSA; In Sosiologi Komunikasi. Jakarta: Universitas Mercubuana.

Kridalaksana, H. (2008). Kamus Linguistik (Keempat). Jakarta: Gramedia Pustaka Utama.

Perdana, A. V. (2019). Kasus Siswi Dibakar di Bangladesh, Perdana Menteri Buka Suara. Retrieved April 27, 2019, from https://internasional.kompas.co $\mathrm{m} / \mathrm{read} / 2019 / 04 / 20 / 23344161 / \mathrm{ka}$ sus-siswi-dibakar-dibangladesh-perdana-menteribuka-suara

Sasangka, S. S. T. W. (2016). Kalimat: Seri Penyuluhan Bahasa Indonesia. Jakarta: Pusat Pembinasaaan Badan 
Pengembangan dan Pembinaan Bahasa Kemendikbud.

Setiawati, S. (2015). Aspek Kohesi Konjungsi dalam Wacana Opini pada Majalah Tempo dan
Implikasinya terhadap

Pembelajaran Bahasa Indonesia.

Gramatika STKIP PGRI

Sumatera Barat, 1(1), 45-56.

https://doi.org/10.22202/jg.2015

.v1i1.1162 